AKRUAL 3 (1) (2011): 86-113 e-ISSN: 2502-6380

AKRUAL

Jurnal Akuntansi

http://fe.unesa.ac.id/ojs/index.php/akrl

\title{
EVALUASI EFEKTIVITAS PELAKSANAAN AUDIT OPERASIONAL AKTIVITAS PELAYANAN JASA PENGINAPAN PADA HOTEL EQUATOR SURABAYA
}

\author{
Rudi Pratono \\ Fakultas Ekonomi Universitas Wijaya Kusuma Surabaya \\ e-mail: rudipranoto@yahoo.com
}

Artikel diterima: 5 Semptember 2011

Terakhir direvisi: 11 November 2011

\begin{abstract}
Abstraksi
Fungsi dasar perhotelan adalah pemberian pelayanan penginapan secara baik demi kepuasan tamu untuk memenuhi fungsi dasar tersebut bagian unit yang terlibat secara langsung maupun tidak langsung, Salah satu unit yang terkait secara langsung adalah unit resepsionis yang betugas melakukan pelayanan terrhadap tamu yang akan menginap. Baik buruk tingkat pelayanan terhadap tamu tergantung pada proses pelayanan yang memuaskan terhadap tamu. Hotel Equator Surabaya menyesuaikan dengan kondisi perkembangan saat ini dengan melakukan langkah kerja audit operasional pada resepsionis hotel dalam penelitian untuk menilai efektivitas. Tujuan dari penelitian ini memberikan gambaran menyeluruh mengenai fungsi pelayanan jasa suatu perusahaan untuk menemukan kelamahan dan hambatan yang akan mengakibatkan kurang maksimal hasil yang diperoleh. Evaluasi mengungkapkan pengendalian intern pada sistem pelayanan yang memerlukan perbaikan-perbaikan demi kepuasan tamu dan meningkatkan kualitas pelayanan hotel tersebut.
\end{abstract}

Kata kunci: Audit operasional, efektivitas, pengendalian intern

\section{PENDAHULUAN}

Kelangsungan hidup suatu perusahaan sangat dipengaruhi oleh efisiensi dan efektivitasnya. Dengan semakin meningkatnya jumlah persaingan, setiap perusahaan dituntut untuk lebih efisien dan unggul dalam setiap kegiatan operasionalnya. Sementara, perusahaan sendiri selalu mengalami keterbatasan dalam memperoleh dana, daya, sarana, dan prasarana kerja. Untuk mencapai efisien dan efektivitas yang diinginkan perusahaan diperlukan suatu evaluasi yang memadai untuk mengukurnya. Evaluasi yang umumnya diadakan oleh perusahaan untuk mencapai tujuan tersebut adalah dilakukan audit pada fungsi operasionalnya, untuk meyakinkan apakah fungsi operasional perusahaan tersebut telah melaksanakan perannya dengan baik, sekaligus memberikan saran untuk meningkatkan keberhasilan dalam mencapai tujuan perusahaan. 
Audit operasional merupakan salah satu sarana untuk mengevaluasi suatu perusahaan (organisasi) secara keseluruhan atau bagian-bagian tertentu saja dalam perusahaan tersebut. Evaluasi ini selalu berpandangan ke depan (forward looking) untuk melihat bagaimana baiknya manajemen mencapai tujuannya dan sekaligus melihat kesulitan operasionalnya. Apabila kemudian ditemukan wilayah potensial timbulnya masalah yang dapat menghambat fungsi operasional tersebut maka ditemukan rekomendasi yang dapat berguna untuk perusahaan.

Tujuan dari audit operasional adalah untuk mengetahui apakah operasi perusahaan tersebut telah sesuai dengan ketentuan, kebijakan dan peraturan yang ada dalam perusahaan, serta untuk mengetahui apakah operasional perusahaan telah lebih baik daripada masa sebelumnya, dan menentukan apakah perusahaan itu serta aktivitas atau programnya telah dikelola secara ekonomis, efisien dan efektif.

Pelaksanaan audit operasional pada perusahaan jasa hotel terhadap aktivitas pelayanan jasa penginapan, diperlukan evaluasi untuk menilai pelaksanaan proses audit yang telah dilaksanakan sebelumnya. Keberhasilan dari pelaksanaan audit operasional dapat dicapai apabila elemen-elemen pelaksanaan audit operasional dapat terpenuhi oleh auditor dalam perusahaan ini, yaitu adanya independensi dari pihak yang melakukan pemeriksaan, dan kemampuan profesional yang layak. Elemen lain yang harus dipenuhi adalah terlaksananya tahapan audit operasional: planning, preliminary investigations, fieldwork, reporting, revaluation, and follow-up.

Berdasarkan latar belakang masalah yang ada, maka dapat dibuat rumusan masalah, yaitu: 'Bagaimana evaluasi efektivitas pelaksanaan audit operasional aktivitas pelayanan jasa penginapan pada Hotel Equator Surabaya?',

\section{TINJAUAN PUSTAKA}

Audit Operasional

Menurut Tunggal (2000:31), definisi dari audit operasional adalah : ',Suatu pencarian yang terorganisasi untuk cara-cara memperbaiki efisien dan efektivitas.',

Maksud diselenggarakan audit adalah untuk menilai tingkat efisien, efektivitas, dan produktivitas perusahaan, terlepas dari pendekatan apakah yang diaudit adalah perusahaan sebagai keseluruhan atau hanya terbatas pada satuan kerja tertentu atau bidang fungsional tertentu saja.

Dari definisi diatas, beberapa hal penting dapat diuraikan sebagai berikut :

1. Proses yang sistematis, dimana pelaksanaan audit operasional meliputi tahaptahap atau prosedur yang logis, terstruktur dan terorganisasi. Termasuk didalamnya perencanaan yang memadai serta pencarian dan pengevaluasian secara obyektif bukti-bukti yang berhubungan dengan aktivitas yang sedang diaudit.

2. Evaluasi operasi organisasi, pengevaluasian kegiatan operasi organisasi harus didasarkan pada kriteria-kriteria yang telah ditetapkan. Dalam audit operasional kriteria-kriteria tersebut sering dinyatakan dengan standar kinerja yang ditetapkan 
oleh manajemen. Audit operasional mengukur derajat hubungan antara kinerja aktual dengan standarnya.

3. Efektivitas, efisiensi, dan ekonomisasi operasi, berkaitan dengan tujuan pelaksanaan audit operasional, yaitu untuk membantu manajemen meningkatkan efektivitas, efisiensi, dan ekonomisasi operasi. Jadi dapat dikatakan audit operasional berorientasi ke masa depan.

4. Pelaporan kepada orang-orang yang tepat, penerimaan audit operasional adalah manajemen atau individual atau agensi yang minta dilakukannya audit. Laporan audit biasanya diberikan kepada direksi atau komite audit.

5. Rekomendasi atau perbaikan-perbaikan berbeda dengan audit laporan keuangan, audit operasional tidak berhenti sampai dilaporan hasil temuan saja, melainkan lebih jauh lagi, yaitu pembuatan rekomendasi untuk perbaikan.

Dari uraian diatas, dapat disimpulkan bahwa audit operasional merupakan suatu proses sistematis dalam mengevaluasi efektivitas, efisiensi, dan ekonomisasi kegiatan operasi perusahaan, termasuk kebijakan akuntansi dan kebijakan operasional yang telah ditentukan manajemen, dan melaporkan hasil evaluasi tersebut ke orang yang tepat serta memberikan rekomendasi atau saran-saran perbaikan.

\section{Tujuan Audit Operasional}

Menurut Tunggal (2000: 12), beberapa tujuan audit operasional adalah sebagai berikut :

1. Obyek audit operasional adalah mengungkapkan kekurangan dan ketidak-beresan dalam setiap unsur yang diuji oleh auditor operasional dan untuk menunjukkan perbaikan apa yang dimungkinkan untuk memperoleh hasil terbaik dari operasi yang bersangkutan .

2. Untuk membantu manajemen mencapai administrasi operasi yang paling efisien.

3. Untuk mengusulkan kepada manajemen cara-cara dan alat-alat untuk mencapai tujuan apabila manajemen organisasi sendiri kurang pengetahuan tentang pengelolaan yang efisien.

4. Audit operasional bertujuan untuk mencapai efisiensi dan pengelolaan.

5. Untuk membantu manajemen, auditor operasional berhubungan dengan setiap fase dari aktivitas usaha yang dapat merupakan dasar pelayanan kepada manajemen.

6. Untuk membantu manajemen pada setiap tingkat dalam pelaksanaan yang efektif dan efisien dari tujuan dan tanggung-jawab mereka.

\section{Kriteria Penilaian Dalam Audit Operasional}

Berbeda dengan audit laporan keuangan, dimana prinsip akuntansi yang diterima umum adalah merupakan kriteria umum untuk mengevaluasi penyajian laporan keuangan dalam kaitannya untuk mengeluarkan pendapat auditor, dalam audit operasional tidak ada kriteria standar semacam SAK (untuk pedoman prinsip akuntansi yang diterima umum di Indonesia). Pada audit operasional kriteria yang 
digunakan adalah dengan menetapkan bahwa tujuan pemeriksaan ini adalah untuk menentukan apakah suatu obyek yang diaudit telah mencapai tingkat efisien dan efektivitas yang diinginkan, dan bila hal tersebut belum tercapai, maka direkomendasikanlah beberapa perbaikan. Hal semacam tersebut membutuhkan sebuah kriteria/ standar yang lebih spesifik sebelum audit manajemen dimulai.

Terdapat beberapa sumber yang dapat digunakan oleh auditor unutk menentukan kriteria evaluasi yang spesifik, seperti yang terdapat dalam Auditing yang ditulis Arens \& Loebbecke (2000: 837), yaitu mencakup :

a. Kinerja historis

Dapat didasarkan pada hasil yang sebenarnya (atau hasil audit) dari periode sebelumnya. Manfaat kriteria ini adalah kriteria tersebut mudah dibuat, tetapi mungkin tidak dapat memberikan pandangan mendalam mengenai seberapa baik atau buruk sebenaranya unit usaha yang diperiksa dalam melakukan sesuatu.

b. Kinerja yang dapat diperbandingkan

Untuk kesatuan yang dapat diperbandingkan, biasanya datanya sudah tersedia. Bila kesatuan yang dapat diperbandingkan berada diluar organisasi, mereka seringkali menyediakan informasi seperti itu. Data ini seringkali juga tersedia pada kelompok industri dan lembaga pemerintahan yang berwenang.

c. Standar rekayasa

Kriteria ini seringkali memakan waktu dan biaya yang cukup besar dalam pengembangannya, karena memerlukan banyak keahlian, akan tetapi hal itu mungkin sangat efektif dalam memecahkan masalah-masalah operasional yang utama dan biaya yang dikeluarkan akan berharga. Beberapa standar juga dapat dikembangkan oleh kelompok industri untuk digunakan oleh semua anggota mereka, sehingga dengan demikian menyebarkan biaya dan mengurangi beban untuk setiap anggotanya.

d. Diskusi kesepakatan

Pihak-pihak yang terlibat dalam proses ini harus meliputi manajemen kesatuan atau orang-orang yang akan mendapat laporan tentang temuan-temuan yang didapat.

Sedangkan untuk memberikan informasi pada manajemen mengenai efektivitas suatu fungsi diperlukan pengukuran efektivitas yang didasarkan pada bukti-bukti dan standar-standar.

Menurut Alenjandro R. Gorospe (Tunggal, 2000: 5), Standar kriteria yang digunakan untuk mengevaluasi kinerja dapat diklasifikasikan sebagai berikut :

1. Undang-undang dan Peraturan Pemerintah

2. Standar Perusahaan

a. Strategi-strategi, rencana dan program yang disetujui

b. Kebijakan dan prosedur yang ditetapkan

c. Struktur organisasi yang telah disetujui

d. Tujuan perusahaan yang telah ditetapkan 
3. Standar dan praktek industri

4. Prinsip organisasi dan manajemen

Praktek manajemen yang sehat, proses dan teknik yang digunakan oleh perusahaanperusahaan yang maju. Kalau tidak ada standar perusahaan yang tertulis, pemikiran dan falsafah pimpinan dapat digunakan sebagai standar untuk penilaian.

\section{Tahap-tahap Audit Operasional}

Dalam melaksanakan audit operasional terdapat tahapan-tahapan yang harus dilaksanakan oleh seorang auditor, tahapan-tahapan ini harus direncanakan terlebih dahulu sebelum seorang auditor melaksanakan pemeriksaan. Hasil-hasil yang diperoleh dari tahapan-tahapan ini akan mempengaruhi keberhasilan pelaksanaan audit. Ada berbagai versi mengenai urutan tahapan-tahapan audit operasional, menurut Tunggal (2000: 26), antara lain :

1. Memilih auditee

Memilih auditee dimulai dengan studi atau survey pendahuluan dari auditee potensial dalam suatu entitas untuk mengidentifikasikan aktivitas-aktivitas yang mempunyai potensial yang paling tinggi dalam arti memperbaiki efektivitas, efisiensi dan ekonomi operasi.

Pemahaman atas auditee yang potensial diperoleh dengan :

a. Menelaah data berkas latar belakang (background data file) dari setiap auditee;

b. Meninjau keliling fasilitas auditee untuk meyakinkan bagaimana perusahaan klien mencapai tujuannya;

c. Mempelajari dokumentasi yang relevan tentang operasi auditee seperti manual kebijakan dan prosedur, bagan arus, kinerja dan standar pengendalian mutu dan uraian jabatan;

d. Melakukan wawancara dengan manajemen aktivitas tentang bidang masalah khusus ( sering disebut entry interview );

e. Menerapkan prosedur analitis untuk mengidentifikasi kecenderungan dan hubungan yang tidak biasa;

f. Melakukan pengujian audit kecil ( mini-audit probes mini- audit test) untuk mengkonfirmasikan atau mengklarifikasi pemahaman auditor atas masalah potensial.

Pemahaman auditor dari setiap auditee didokumentasikan melalui kuesioner yang diselesaikan, bagan arus dan memorandum naratif. Berdasarkan pemahaman ini, auditor menyiapkan laporan studi pendahuluan atau memorandum, yang mengikhtisarkan temuan dan mencakup rekomendasi tentang auditee yang akan diaudit. Laporan adalah penggunaan eksklusif oleh departemen audit intern, bukan suatu laporan manajemen.

2. Merencanakan audit operasional

Penaksiran resiko ( risk assessment) merupakan bagian utama dari proses perencanaan. Penaksiran resiko adalah untuk tujuan menetapkan bidang-bidang 
untuk ditekankan dalam audit operasional, sebagai kebalikan dari penaksiran resiko dalam audit keuangan eksternal yang tujuannnya untuk menentukan sifat, waktu dan luasnya prosedur audit yang akan dilakukan. Dalam hal ini auditor mungkin menggunakan kuesioner, bagan arus, tanya jawab, laporan manajemen, manual kebijakan dan observasi dalam pelaksanaan survey pendahuluan. Kuesioner mencakup pertanyaan-pertanyaan yang berhubungan dengan masalahmasalah yang mempengaruhi efektivitas, efisiensi dan kinerja operasi.

3. Melaksanakan audit

Auditor operasional harus mengumpulkan bukti yang cukup kompeten agar dapat menjadi dasar yang layak guna menarik suatu simpulan mengenai tujuan yang sedang diuji.

4. Pelaporan dan tindak lanjut

Gabungan kedua faktor ini mengakibatkan banyak perbedaan dalam laporan audit operasional. Penulisan laporan seringkali banyak memakan waktu agar temuan dan rekomendasi audit dapat disampaikan secara jelas.

5. Melakukan tindakan korektif apabila diperlukan.

6. Melaporkan hasil kepada tingkat otoritas yang tepat.

7. Melakukan tindak lanjut.

\section{Pengertian Efektivitas}

Menurut Sawyer (2005 : 211), menyatakan bahwa:'Efektivitas adalah menekankan hasil aktual dari dampak atau kekuatan untuk menghasilkan dampak tertentu." sedangkan efektivitas yang dikemukakan oleh Agoes (1996: 180), yaitu : "'Efektif, apabila suatu tujuan, sasaran, program dapat tercapai batas waktu yang ditargetkan, tanpa memperdulikan biaya yang dikeluarkan.',

Dari kedua definisi tersebut dapat disimpulkan bahwa efektivitas merupakan hasil yang akan dicapai berdasarkan metode-metode dan kriteria-kriteria yang telah ditentukan sebelumnya. Dengan kata lain penilaian efektivitas didasarkan pada sejauh mana suatu organisasi dapat terpenuhi dan berhubungan dengan melakukan yang benar dan terkait dengan tujuan tersebut.

\section{Kriteria Penentuan Efektivitas Dalam Pelaksanaan Audit Operasional}

Efektivitas dalam pelaksanaan audit operasional dapat dicapai apabila tahapan- tahapan dalam audit operasional dapat dilaksanakan dengan baik, sehingga tujuan pelaksanaan audit operasional tersebut dapat tercapai. Pada setiap tahapan tersebut terdapat kriteria yang harus dipenuhi. Kriteria yang digunakan dapat merupakan standar/ pedoman yang digunakan untuk menilai kinerja auditor dalam melakukan pemeriksaan.

Efektivitas dari penyelenggaraan audit dapat dicapai dengan melaksanakan prinsip-prinsip, yaitu :

1. Audits indicate if adequate control are in place;

2. Auditors are competent; 


\section{AKRUAL}

Jurnal Akuntansi

http://fe.unesa.ac.id/ojs/index.php/akrl

3. Auditors are proficient, fact-based, and performed profeddionally,

4. Audits result in information that meets auditee needs and allows problems to be corrected, and

5. Audit systems are managed for excellence.

Kriteria yang digunakan dalam efektivitas adalah standar audit internal yang umum dipakai dalam pelaksanaan audit operasional yaitu Norma Praktek Profesional Audit Internal dengan rincian sebagai berikut :

1. Independensi

Auditor harus mandiri dan terpisah dari kegiatan yang diperiksanya. Auditor dianggap mandiri apabila dapat melaksanakan pekerjaannya secara bebas dan obyektif. Kemandirian para pemeriksa dapat memberikan penilaian yang tidak memihak dan tanpa prasangka, sehingga sangat penting bagi pemeriksa sebagaimana mestinya. Hal yang berkaitan dengan independensi antara lain :

\section{a. Status organisasi}

Status organisasi unit audit internal (bagian pemeriksaan internal) haruslah memberikan keleluasaan untuk memenuhi atau menyelesaikan tanggungjawab pemeriksa yang diberikan.

b. Obyektifitas

Para pemeriksa internal haruslah melakukan pemeriksaan secara obyektif.

2. Kemampuan profesional

Kemampuan profesional merupakan tanggung jawab bagian audit internal dan setiap auditor internal. Pimpinan audit internal dalam setiap pemeriksaan haruslah menugaskan orang-orang yang secara bersama atau keseluruhan memiliki pengetahuan, kemampuan, dan berbagai disiplin ilmu yang diperlukan untuk melaksanakan pemeriksaan secara tepat dan pantas. Dalam hal ini terdapat beberapa kriteria pendukung sebagai berikut :

a. Berkaitan dengan unit audit internal, mencakup : (1) personalia, (2) pengetahuan dan kecakapan, (3) pengawasan;

b. Auditor internal, mencakup : (1) kesesuaian dengan standar profesi, (2) pengetahuan dan kecakapan, (3) hubungan antar manusia dan komunikasi, (4) pendidikan berkelanjutan, (5) ketelitian professional.

3. Pelaksanaan kegiatan pemeriksaan

Kegitan pemeriksaan harus meliputi perencanaan pemeriksaan, pengujian dan pengevaluasian informasi, pemberitahuan hasil dan menindak lanjuti (follow up). Pemeriksa internal harus bertanggung jawab untuk merencanakan dan melaksanakan tugas pemeriksaan, yang harus disetujui dan ditinjau atau direview oleh pengawas.

a. Perencanaan pemeriksaan

Pemeriksa haruslah merencanakan setiap pemeriksaan

b. Pengujian dan pengevaluasian informasi

Pemeriksa internal harus mengumpulkan, menganalisis, menginterprestasi, dan membuktikan kebenaran informasi untuk mendukung hasil pemeriksaan. 
c. Penyampaian hasil pemeriksaan

Pemeriksa internal harus melaporkan hasil-hasil pemeriksaan yang diperoleh dari kegiatan pemeriksaan.

d. Tindak lanjut hasil pemeriksaan

Pemeriksa internal harus terus meninjau atau melakukan follow up untuk memastikan bahwa terdapat temuan-temuan pemeriksaan yang telah dilaporkan telah dilakukan tindak lanjut yang tepat.

\section{Audit Operasional Aktifitas Pelayanan Jasa}

Audit opersional aktifitas pelayanan jasa ditujukan untuk menganalisis efektivitas kemampuan perusahan dalam menghasilkan jasa sebagai operasi utama perusahaan. Tujuan audit operasional aktivitas pelayanan jasa yaitu :

a. Menilai kegiatan yang berhubungan dengan operasional perusahaan;

b. Mendeteksi adanya kelemahan dalam kegiatan operasional perusahaan;

c. Mencari alternatif peningkatan kegiatan operasional perusahaan;

d. Mengembangkan rekomendasi dalam menemukan kelemahan.

Dalam lingkup pelaksanaan audit operasional tersebut harus memuat temuantemuan audit yang berhubungan dengan tujuan pemeriksaan yang didasarkan pada :

1. Kriteria

Merupakan berbagai standar, ukuran, atau harapan yang digunakan dalam melakukan evaluasi dan atas verifikasi (apa yang seharusnya terdapat) yang digunakan dan berkaitan dengan operasional yang diperiksa.

2. Kondisi

Merupakan berbagai bukti nyata yang ditemukan oleh pemeriksa dalam pelaksanaan pemeriksaan (apa yang ternyata terdapat) dalam kegiatan yang berkaitan dengan operasional yang diperiksa.

3. Sebab

Yaitu alasan yang dikemukakan atas terjadinya perbedaan antara kondisi yang diharapkan dan kondisi sesungguhnya (mengapa terjadinya perbedaan).

4. Akibat

Berbagai resiko atau kerugian yang dihadapi operasional dan atau unit kerja lainnya yang berkaitan dengan kegiatan operasional dalam perusahaan karena terdapatnya kondisi yang tidak sesuai dengan kriteria (dampak dari perbedaan).

\section{METODE PENELITIAN}

\section{Pendekatan Penelitian}

Penelitian ini menggunakan pendekatan kualitatif deskriptif, yaitu prosedur penelitian yang menghasilkan data deskriptif berupa kata-kata tertulis atau lisan dari orang-orang atau perilaku yang diamati (Moleong, 2000: 3), hal tersebut dapat dijabarkan sebagai berikut:

1. Penelitian dilakukan pada latar ilmiah atau pada konteks keseluruhan. Penulis melakukan penelitian pada PT. Equator Dayatama Semesta. 


\section{AKRUAL}

Jurnal Akuntansi

http://fe.unesa.ac.id/ojs/index.php/akrl

2. Manusia sebagai alat, maksudnya manusia merupakan pengumpul, pengolah dan menganalisa data;

3. Data yang dikumpulkan bersifat deskriptif. Profil perusahaan dan data lainnya dikumpulkan untuk mendapatkan gambaran situasi perusahaan, dikumpulkan juga dilihat dari aspek kualitatifnya.

Strategi penelitian yang digunakan dalam penelitian ini adalah studi evaluasi, berdasarkan rumusan masalah yang ada. Dimana menurut Moleong (2000: 62), menyebutkan bahwa dari rumusan masalah yang ada dapat dibagi menjadi tiga, yaitu:

"masalah" untuk peneliti, '"evaluands" untuk evaluator, dan "'pilihan kebijaksanaan' untuk peneliti kebijaksanaan. Maka fokus penulis dalam penelitian ini adalah sebagai evaluator untuk menilai efektivitas pelaksanaan audit operasional yang telah dilaksanakan oleh Satuan Pengawasan Intern PT. Equator Dayatama Semesta. Menurut Moleong (2000: 178), Teknik keabsahan data yang digunakan adalah triangulasi, dengan cara:

1. Membandingkan data hasil pengamatan dengan data hasil wawancara;

2. Membandingkan hasil wawancara dengan isi suatu dokumen yang berkaitan.

\section{Ruang Lingkup Analisis}

Pembatasan ruang lingkup penelitian ini dilakukan karena penulis menyadari adanya keterbatasan waktu, data yang diperoleh, tenaga, serta kemampuan dan pengetahuan yang dimiliki penulis. Agar hasil pembahasan dapat mencapai sasaran dan fokus yang dituju, maka penulis membatasi lingkup penelitian pada hal-hal sebagai berikut :

1. Penelitian difokuskan pada peristiwa yang telah terjadi yaitu pada penilaian atas efektivitas pelaksanaan audit operasional aktifitas pelayanan jasa penginapan pada Hotel Equator Surabaya oleh Satuan Pengawasan Intern PT. Equator Dayatama Semesta.

2. Penelitian meliputi perencanaan, pelaksanaan sampai dengan laporan hasil audit operasional pelayanan jasa penginapan hotel. Dalam penelitian ini digunakan pendekatan kesesuaian yang mengacu pada peraturan yang ditetapkan oleh pemerintah maupun standar dan kebijakan serta prosedur yang telah ditetapkan oleh perusahaan.

\section{Jenis dan Sumber Data}

Jenis data yang digunakan oleh penulis adalah data primer dan data sekunder yang bersumber dari perusahaan dan literature review. Sumber data utama adalah data dan hasil dari pelaksanaan audit operasional pelayanan jasa hotel, yaitu dokumen yang dibuat atau dikumpulkan dan disimpan auditor mengenai prosedur pemeriksaan yang dijalankan, pengujian yang dilakukan, keterangan yang diperoleh dan kesimpulan. Sumber data primer lain berasal dari wawancara dengan kepala dan staf Satuan Pengawasan Intern. Pengumpulan data primer lainnya berhubungan dengan efektivitas pelaksanaan audit operasional dilakukan dengan kuesioner, yaitu: 
AKRUAL 3 (1) (2011): 86-113 e-ISSN: 2502-6380

\section{AKRUAL}

Jurnal Akuntansi

http://fe.unesa.ac.id/ojs/index.php/akrl

1. Penilaian pelaksanaan audit operasional, meliputi: independensi, kemampuan profesional;

2. Penilaian efektivitas pelaksanaan audit operasional, meliputi: perencanaan, pengujian, pengevaluasian informasi, pemberitahuan hasil, menindak lanjuti hasil pemeriksaan.

Sedangkan data sekunder yang digunakan berupa profil perusahaan, struktur organisasi, sistem dan prosedur yang berkaitan dengan operasional pelayanan jasa penginapan hotel.

\section{Prosedur Pengumpulan Data dan Teknik Analisis Data}

Prosedur pengumpulan data yang digunakan oleh penulis adalah studi pustaka, survey pendahuluan dan studi lapangan.

Teknik analisis data yang digunakan penulis dalam penelitian ini adalah :

1. Mempelajari profil perusahaan untuk mendapatkan gambaran umum dan karakteristik PT. Equator Dayatama Semesta.

2. Mempelajari sistem dan prosedur operasional pelayanan jasa penginapan Hotel Equator.

3. Mempelajari lingkup tanggung jawab dan struktur yang berkaitan dengan Satuan Pengawasan Intern yang melaksanakan audit operasional.

4. Melakukan evaluasi terhadap efektivitas tahap pelaksanaan berdasarkan pada kriteria-kriteria yang telah ditentukan sebelumnya dengan alat ukur kuesioner yang telah disiapkan berkaitan dengan independensi auditor yang melaksanakan audit operasional, kemampuan profesional, serta pelaksanaan kegiatan pemeriksaan

5. Menarik kesimpulan berdasarkan data-data ynag telah dikumpulkan sebelumnya berkaitan dengan efektivitas pelaksanaan audit operasional berdasarkan kriteria yang telah ditetapkan serta kenyataan di lapangan. 


\section{PEMBAHASAN}

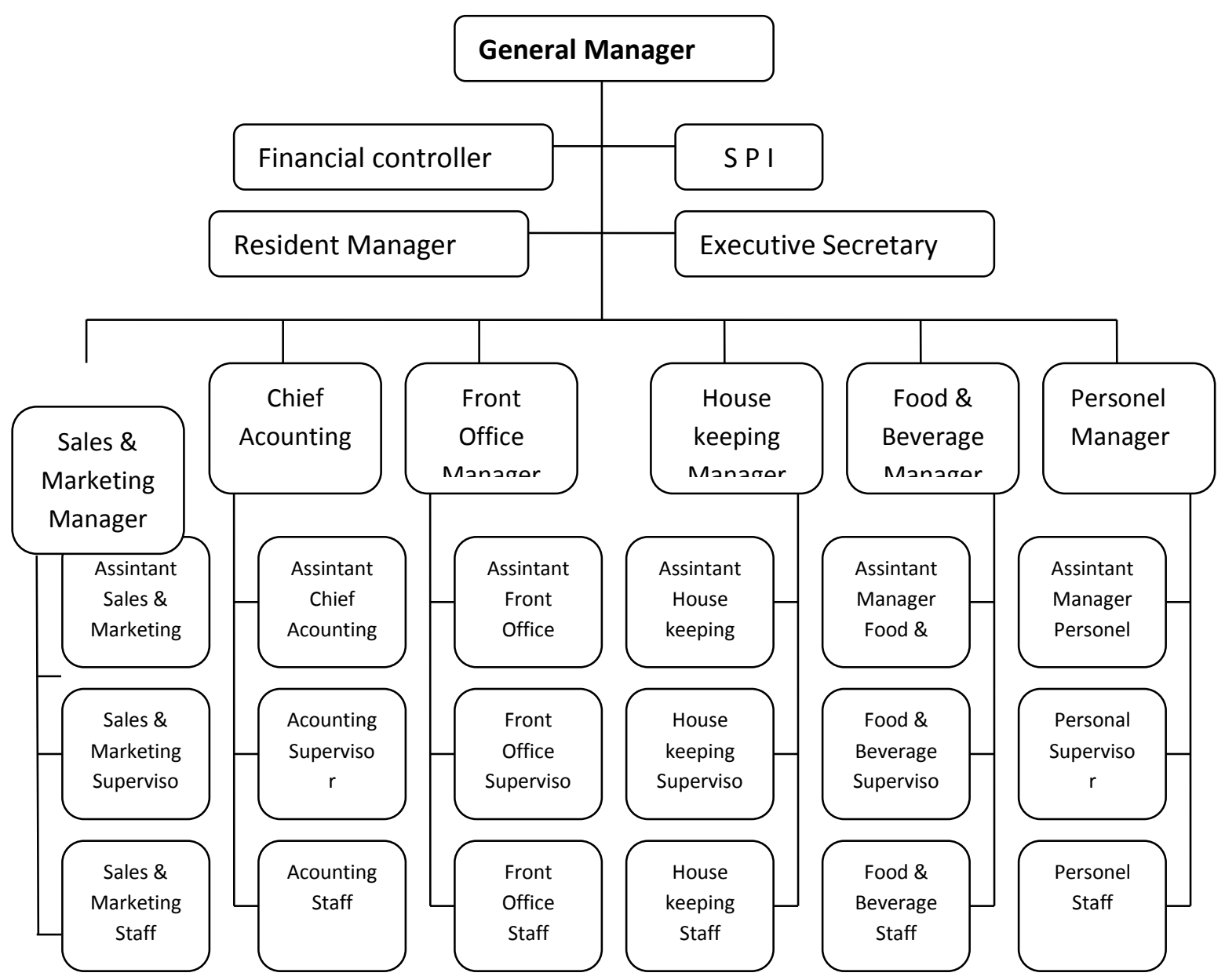

Sumber : Bagian Personalia Hotel Equator Surabaya

\section{Gambar 1. Struktur Organisasi Hotel Equator Surabaya}

Bentuk Organisasi yang ada pada saat ini adalah organisasi lini, dengan demikian diharapkan tugas, wewenang dan tanggung jawab dari masing-masing bagian akan lebih jelas terutama akan terjalin kerjasama yang baik antara unit atau lini.

Proses pelayanan penginapan Hotel Equator Surabaya dimulai dari tamu/ guest dan berakhir di tamu/ guest pula. Keterangan flowchart pemberian pelayanan penginapan:

1. Guest/ tamu mengajukan permohonan untuk menginap di Hotel Equator Surabaya dengan mengisi formulir persyaratan yang telah disediakan (PR). 
AKRUAL 3 (1) (2011): 86-113 e-ISSN: 2502-6380

\section{AKRUAL}

Jurnal Akuntansi

http://fe.unesa.ac.id/ojs/index.php/akrl

2. Pihak Hotel Equator Surabaya bagian Receptionis melakukan wawancara dengan calon tamu/ guest yang akan menggunakan fasilitas yang disediakan oleh pihak hotel.

3. Pihak Hotel Equator Surabaya melakukan verifikasi data atas pengajuan menginap pada Hotel Equator Surabaya dan kemudian mengelompokkan data penggunaan layanan hotel.

4. Kemudian pihak hotel mengajukan pembayaran dengan Down Payment untuk kepastian tamu/guest telah melaksanakan transaksi penyewaan penginapan.

5. Pihak tamu menyetujui pelaksanaan pembayaran Down Payment untuk penggunaan fasilitas yang akan disewa.

6. Pihak hotel membuat bukti pembayaran atas Down Payment dan menyerahkan kunci kamar yang akan disewa pada tamu/guest.

7. Guest/ tamu menginap sesuai dengan permintaan.

8. Jika terjadi komplain maka guest/ tamu harus mengisi daftar yang disediakan oleh hotel (RK).

9. Daftar komplain yang berasal dari guest/ tamu akan diproses oleh pihak manajemen hotel.

10. Pihak manajemen hotel akan menganalisa daftar komplain dari tamu. Hasil analisis tersebut akan dikaji oleh pihak manajemen untuk digunakan sebagai acuan akan kekurangan dari pelayanan hotel kapada guest/ tamu. Kemudian diberikan kepada receptionis untuk selanjutnya diterbitkan Surat Perintah Kerja (SPK).

11. Receptionis melaksanakan Surat Perintah Kerja dari pihak manajemen hotel. Jika terlaksana receptionis membuat Surat Selesai Pelaksanaan (SSP).

PR-RK merupakan proses transaksi penginapan dimana tamu dalam mengajukan permohonan penginapan dan harus mematuhi aturan-aturan pembayaran yang telah ditetapkan oleh pihak hotel sampai dengan proses menginap.

RK-SPK merupakan proses transaksi komplain yang diajukan oleh tamu kepada pihak manajemen hotel.

SPK-SSP merupakan proses akhir penyelesaian komplain, dengan diterbitkannya Surat Selesai Pelaksanaan (SSP) komplain dari tamu.

PR-SSP merupakan total waktu penyelesaian komplain. 
AKRUAL 3 (1) (2011): 86-113 e-ISSN: 2502-6380

AKRUAL

Jurnal Akuntansi

http://fe.unesa.ac.id/ojs/index.php/akrl

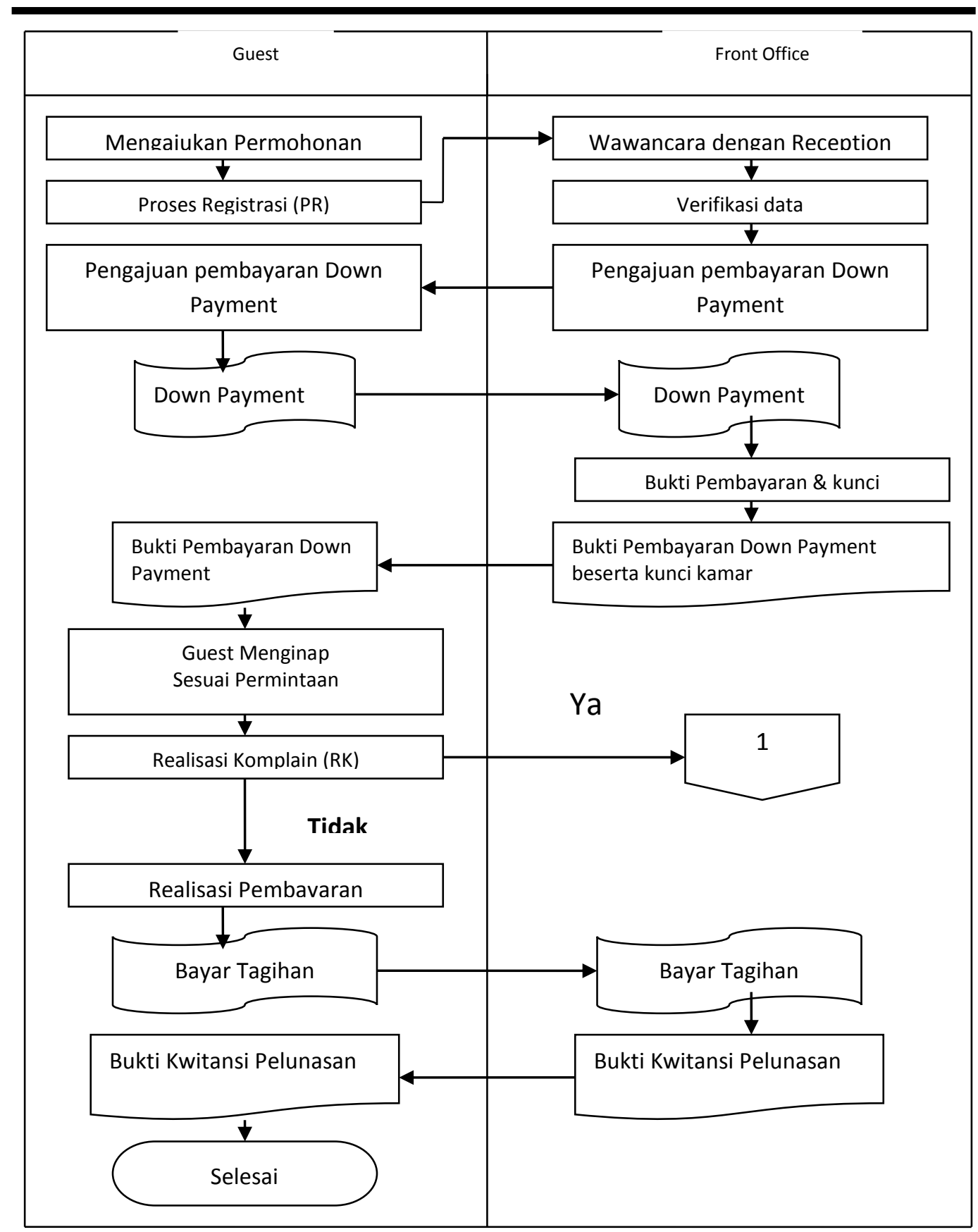

Sumber : Data Intern Perusahaan (Diolah)

Gambar 2. Transaksi Penginapan

\section{Kedudukan Satuan Pengawasan Intern (SPI)}

Kedudukan Satuan Pengawasan Intern (SPI) telah ditetapkan PT. Equator Dayatama Semesta. Struktur Organisasi tersebut telah dilengkapi dengan uraian 
tugas, fungsi, tanggung jawab dan wewenang. SPI berada langsung dibawah dan tanggung jawab kepada General Manager. Satuan Pengawasan Intern dipimpin oleh seorang kepala dan dalam melaksanakan tugasnya dibantu oleh Pengawas bidang. Kepala Satuan Pengawasan Intern membawahi :

a. Pengawas Bidang Teknik dan Umum

b. Pengawas Bidang Keuangan dan Personalia

c. Pengawas Bidang Operasi, Pemasaran, Perencanaan dan Pengembangan

d. Para auditor sebagai pejabat fungsional yang secara administratif bertanggung jawab kepada pengawas bidang masing-masing

Dalam proses pemeriksaan organisasi penugasan adalah sebagai berikut :

a. Kepala Satuan Pengawasan Intern : Sebagai penanggung jawab

b. Pengawas Bidang : Sebagai pengawas dalam proses pemeriksaan

c. Senior Auditor

: Sebagai ketua tim audit

d. Yunior Auditor

: Sebagai auditor

e. Assisten Auditor

: Sebagai auditor

\section{Audit Operasional Pelayanan Jasa Penginapan Hotel Equator Surabaya}

Audit operasional pelayanan jasa penginapan hotel merupakan audit operasional yang dilaksanakan oleh SPI Hotel Equator Surabaya. Unit kerja yang menjadi fokus aktivitas pelayanan jasa adalah divisi-divisi terkait dengan keseluruhan aktivitas pelayanan jasa penginapan hotel.

Pelaksanaan audit operasional pelayanan jasa penginapan hotel dilakukan oleh SPI. Tujuan pelaksanaan audit operasional aktivitas pelayanan jasa penginapan hotel adalah untuk meyakinkan bahwa :

1. Sistem pelayanan jasa penginapan telah dilaksanakan dengan baik.

2. Kegiatan pelayanan jasa penginapan telah dilaksanakan secara efisien, ekonomis dan efektif.

3. Kebijakan pelayanan hotel telah sesuai dengan ketentuan yang berlaku.

4. Manfaat pelayanan hotel dapat mendukung tercapainya tujuan perusahaan yang telah ditetapkan.

5. Pelayanan kepada tamu/ guest memuaskan.

\section{Prosedur Pelaksanaan Audit Operasional Aktivitas Pelayanan Jasa Penginapan Perencanaan kegiatan audit}

Kegiatan perencanaan pemeriksaan diawali dengan penyusunan tim, pembuatan surat tugas, survei pendahuluan dan pembuatan program pemeriksaan. Kegiatan perencanaan dimulai pada setiap tahunnya, SPI membuat Program Kerja Audit Tahunan (PKAT). Dalam PKAT tersebut ditentukan obyek audit yang akan diperiksa. Tahap selanjutnya adalah pembuatan surat tugas yang sudah ditanda tangani kemudian ditujukan kepada pimpinan unit kerja yang diperiksa.

Survei pendahuluan kemudian dilaksanakan dengan mempelajari sistem dan prosedur pelayanan jasa penginapan pada Hotel Equator Surabaya, serta ketentuan 
lain yang berhubungan dengan aktivitas pelayanan jasa penginapan seperti Standar Operating Procedure (SOP) yang sudah ditetapkan perusahaan tentang pelaksanaan pelayanan jasa penginapan dan tarif kamar untuk para tamu yang akan menginap.

Dalam tahap ini, beberapa anggota tim audit melakukan observasi langsung terhadap pelaksanaan pelayanan penginapan mulai dari front office departemen sampai dengan pelaksanaan teknis lapangan. Survei pendahuluan juga dilakukan dengan mengadakan pembicaraan awal dengan manajer pada departemen terkait bersamaan dengan penyerahan surat tugas. Setelah survei pendahuluan dilaksanakan, tahap selanjutnya adalah penyusunan program kerja pemeriksaan.

\section{Program audit operasional aktivitas pelayanan jasa penginapan hotel}

Penyusunan program audit operasional pelayanan jasa penginapan hotel berdasarkan kertas kerja audit tahunan sebelumnya dan hasil evaluasi sistem pengendalian manajemen. Program audit pelayanan jasa penginapan sebenarnya telah ada (terprogram sebelumnya) dan bersifat standar. Hal ini terjadi karena pemeriksaan pada obyek audit relatif sama dan terstruktur dengan tahun-tahun sebelumnya.

Namun demikian tidak menutup kemungkinan bahwa program audit tersebut lebih bersifat fleksibel, artinya dapat terjadi dalam pelaksanaannya dapat ditambah apabila diperlukan dan dapat dikurangi apabila tidak diperlukan. Dalam program audit memuat tujuan audit, ruang lingkup audit, instruksi umum dan program pemeriksaan.

\section{Kertas Kerja Audit}

Kertas kerja audit adalah dokumen pemeriksaan yang harus dibuat oleh auditor. Didalam kertas kerja audit memuat informasi dan bukti yang dikumpulkan selama proses pemeriksaan (audit). Format kertas kerja audit terdiri dari : nomor kertas kerja, unit kerja auditee, periode audit, data tim auditor dan pengawas tim audit. Kertas kerja audit yang dibuat oleh SPI PT. Equator Dayatama Semesta telah memuat dengan lengkap proses audit, peraturan (norma) yang digunakan sebagai sumber kriteria bukti audit, dokumen yang berkaitan dengan prosedur pelayanan hotel.

1. Tujuan audit

Pernyataan tujuan yang ingin dicapai dari pelaksanaan audit yang dijalankan yaitu untuk meyakinkan efektivitas dan efisiensi aktivitas pelayanan jasa penginapan hotel.

2. Peraturan/ norma yang digunakan sebagai sumber kriteria bukti audit, berupa :

a. Surat keputusan manajer tentang sistem dan prosedur pelayanan jasa penginapan hotel

b. Surat keputusan manajer tentang tarif kamar hotel

c. Instruksi manager tentang pelaksanaan sistem pelayanan jasa penginapan di Hotel Equator Surabaya

d. Peraturan-peraturan lainnya yang berkaitan dengan pelayanan jasa hotel. 
AKRUAL 3 (1) (2011): 86-113 e-ISSN: 2502-6380

AKRUAL

Jurnal Akuntansi

http://fe.unesa.ac.id/ojs/index.php/akrl

3. Dokumen yang berkaitan dengan aktivitas pelayanan jasa penginapan hotel, antara lain :

a. Reservation form ( formulir reservasi )

Reservation form berisi data-data mengenai tamu yang akan menginap, dari mana guest berasal, tipe kamar dan jumlah kamar yang dipesan, harga kamar yang dipakai, kapan guest akan check in dan check out.

b. Receipt voucher

Digunakan untuk mencatat uang yang masuk di Front Office Cashier.

c. Paid out voucher

Digunakan untuk mencatat uang yang keluar di Front Office Cashier.

d. Rebate Voucher

Digunakan untuk mengoreksi sejumlah transaksi yang telah diposting.

e. Front Office Cashier Summary

Digunakan untuk mencatat pemasukan dan pengeluaran pada front office cashier.

f. Guest Account

Digunakan untuk mencatat semua transaksi yang telah dilakukan oleh tamu

g. Struktur organisasi dan deskripsi jabatan masing-masing pegawai.

4. Kuisioner pengendalian manajemen

Kuisioner pengendalian manajemen bertujuan untuk mengetahui efektivitas pengendalian manajemen guna mendukung tercapainya tujuan perusahaan. Kuisioner ini ditujukan kepada manajer yang berkaitan dengan aktivitas pelayanan jasa penginapan. Didalam Kuisioner pengendalian mencakup :

a. Pengorganisasian

Bertujuan untuk mengetahui efektivitas pengendalian organisasi dengan memperhatikan adanya pemisahan fungsi perencanaan, pelaksanaan dan pengawasan aktivitas pelayanan jasa penginapan serta adanya koordinasi antara unit yang saling mendukung.

b. Kebijakan/ aturan

Untuk mengetahui sejauh mana tingkat kesesuaian antara peraturan/ kebijakan yang ada berkaitan dengan pelayanan penginapan hotel benar-benar dijalankan sebagaimana mestinya.

c. Prosedur-prosedur

Untuk mengetahui sejauh mana prosedur-prosedur aktivitas pelayanan jasa penginapan telah dijalankan dengan baik.

d. Personalia/ Sumber Daya Manusia

Untuk mengetahui pengelolaan sumber daya manusia pada aktivitas pelayanan jasa penginapan berkaitan dengan kecukupan personil, standar kualifikasi (keahlian khusus) yang diperlukan dalam melaksanakan kegiatan pemanduan, data entry, telekomunikasi dan verifikasi perhitungan pendapatan jasa pelayanan hotel. 
e. Perencanaan

Untuk mengetahui efektivitas kegiatan perencanaan hotel berkaitan dengan kesiapan fasilitas dan peralatan, jadwal kegiatan pelayanan tamu/ guest yang akan menginap.

f. Pembukuan/ akuntansi

Untuk mengetahui efektivitas pengendalian akuntansi berkaitan dengan pencatatan rencana harian tamu check in sampai check out.

g. Pelaporan

Untuk mengetahui efektivitas pelaporan yang dibuat oleh departemen berhubungan dengan realisasi pelayanan jasa penginapan yang telah dilaksanakan dalam laporan kunjungan tamu.

h. Pengawasan manajemen

Untuk mengetahui efektivitas pengawasan manajemen berkaitan dengan kesesuaian antara pelaksanaan jasa penginapan dengan instruksi kerja, pengawasan dokumen, pengawasan dan evaluasi kegiatan operasional serta pengendalian jasa pelayanan penginapan hotel, pengawasan terhadap kebersihan, kerapian, ketertiban pemakaian fasilitas, pengawasan mutu pelayanan.

5. Langkah kerja audit

Dalam langkah kerja audit berisi prosedur yang harus dilakukan oleh auditor mulai dari mempelajari ketentuan yang berlaku berkaitan dengan pelayanan jasa penginapan, memeriksa jurnal kedatangan, pemeriksaan bukti pendukung, verifikasi terhadap ketepatan data yang berhubungan dengan perhitungan tarif, memeriksa nilai investasi yang dikeluarkan untuk fasilitas kamar hotel, meghitung kinerja pelayanan hotel, membandingkan nilai investasi dan anggaran yang telah dibuat sebelumnya, serta kesesuaian antara laporan bulanan, triwulanan dan tahunan yang telah dibuat oleh auditee. Dalam tahap pelaksanaan audit ini, auditor banyak menggunakan sistem informasi komputer dalam proses penelusuran (tracing) bukti audit, karena sebagian besar proses administratif aktivitas pelayanan jasa hotel telah menggunakan aplikasi sistem berbasis komputer. Untuk mendukung proses audit yang telah dijalankan auditor juga membuat kertas kerja pendukung, seperti :

a. Daftar personil/ sumber daya manusia pada aktivitas pelayanan hotel

b. Data arus proses penginapan

c. Kekuatan alat produksi pelayanan hotel

d. Investasi sarana pelayanan hotel

e. Pendapatan pelayanan hotel

f. Biaya jasa pelayanan hotel

g. Perbandingan laba/ rugi jasa pelayanan hotel

h. Kinerja pelayanan hotel

i. Kelengkapan administrasi 
j. Penyelesaian dokumen pelayanan hotel

k. Penyampaian laporan manajemen pelayanan hotel.

\section{Hasil temuan audit operasional aktivitas pelayanan jasa penginapan hotel}

Sebagai hasil dari pelaksanaan audit operasional aktivitas pelayanan jasa penginapan hotel pada PT. Equator Dayatama Semesta adalah adanya temuan hasil audit. Temuan audit yang telah dijalankan oleh Satuan Pengawasan Intern terdiri atas dua jenis, yaitu temuan hasil audit positif dan temuan hasil audit negatif. Temuan hasil audit positif adalah temuan atas pelaksanaan kegiatan pelayanan hotel yang perlu dipertahankan dan ditingkatkan. Sedangkan temuan negatif adalah temuan atas terjadinya penyimpangan atau ketidakefektifan dan efisiensi atas aktivitas pelayanan jasa penginapan sehingga diperlukan adanya rekomendasi dari auditor. Dalam audit operasional yang telah dilaksanakan ada beberapa temuan negatif yang antara lain :

1. Kondisi

Adanya kamar hotel dengan fasilitas yang tidak sesuai dengan standar kamar yang ditetapkan

i. Kriteria

Tiap-tiap jenis kamar diberikan fasilitas-fasilitas yang sudah menjadi ketetapan/ standar hotel tersebut

ii. Penyebab

Kurangnya pengecekan oleh pelayan hotel terhadap tiap-tiap kamar hotel sebelum tamu/ guest memasuki kamar hotel tersebut, seperti air conditioning, refrigator, shower bathroom, telepon dan televisi yang mengalami sedikit trobel.

iii. Akibat

Terjadinya komplain dari tamu/ guest yang menginap terhadap ketidakpuasan akan fasilitas yang sudah dijanjikan

iv. Rekomendasi

Melakukan pengecekan secara menyeluruh terhadap kamar hotel setiap harinya dan pengecekan kembali sebelum tamu tiba ke kamar hotel tersebut dan bila ada masalah/ trobel sebaiknya dikonfirmasikan dengan housekeeping departemen.

2. Kondisi

Skill yang dimiliki oleh pegawai kurang memadai

i. Kriteria

Pegawai/ pelayan hotel harus sudah mampu menguasai tugasnya dengan tepat.

ii. Penyebab

Adanya pegawai/ pelayan hotel yang sedang magang

iii. Akibat

Pelaksanaan tugas tersebut kurang cepat dikarenakan pegawai/ pelayan hotel tersebut masih dalam tahap belajar 
AKRUAL 3 (1) (2011): 86-113 e-ISSN: 2502-6380

AKRUAL

Jurnal Akuntansi

http://fe.unesa.ac.id/ojs/index.php/akrl

iv. Rekomendasi

Memberikan pendamping kepada pegawai/ pelayan hotel yang sedang magang.

\section{Kondisi}

Adanya keterlambatan pelayanan dan kurangnya keramah tamahan terhadap tamu/ guest disaat banyaknya tamu/ guest yang menginap.

i. Kriteria

Pelayanan terhadap tamu/ guest harus sesuai dengan misi Hotel Equator Surabaya.

ii. Penyebab

Kurangnya jumlah karyawan, dimana jumlah karyawan bagian umum tidak sebanding dengan jumlah kamar yang tersedia.

iii. Akibat

Timbul rasa kekecewaan para tamu dengan pelayanan yang lambat.

iv. Rekomendasi

Perlu diterbitkannya surat perintah kerja lembur bila terjadi banyak tamu yang menginap dan perlu untuk merekrut karyawan baru.

4. Kondisi

Penyampain informasi yang dibutuhkan tamu, baik mengenai fasilitas dalam hotel maupun luar hotel yang kurang jelas

i. Kriteria

Seluruh karyawan hotel harus sudah mengetahui fasilitas-fasilitas apa saja yang disediakan dan fungsi-fungsinya oleh Hotel Equator Surabaya.

ii. Penyebab

Kurangnya pemberian informasi terhadap karyawan hotel terutama terhadap karyawan baru dan pegawai magang.

iii. Akibat

Terjadinya ketidakpuasan tamu terhadap informasi yang diberikan serta terjadinya melemparkan pertanyaan tamu kepada karyawan lain.

iv. Rekomendasi

Memberikan pelatihan dan penyampaian informasi pelayanan yang disediakan Hotel Equator Surabaya secara rutin.

Berkaitan dengan ketidaksesuaian prosedur hendaknya mematuhi sistem dan prosedur-prosedur yang sudah ada, meningkatkan koordinasi antar departemen, peningkatan sistem informasi dan pengendalian internal.

\section{Laporan Hasil Pemeriksaan (LHP)}

Laporan hasil audit merupakan laporan yang berfungsi sebagai media bagi tim audit untuk menyatakan tujuan dan ruang lingkup pemeriksaan yang telah dilakukan serta melaporkan temuan-temuan selama audit dan kesimpulan hasil pemeriksaan beserta rekomendasi perbaikannya. Sebelum terbitnya laporan hasil pemeriksaan, proses yang penyusunannya dimulai dengan adanya temuan audit. Setelah 
pembahasan oleh tim audit, kemudian dikonfirmasikan dengan departemen terkait dengan temuan hasil audit sementara. Menjelang akhir masa audit dilakukan rapat pembahasan hasil temuan audit. Dalam rapat tersebut dihadiri oleh Tim audit, Manajer divisi terkait, General Manajer, Komite audit yang telah dibentuk oleh Dewan Direksi, serta kepala Satuan Pengawasan Intern sebagai penengahnya. Hasil pembahasan dalam rapat tersebut adalah laporan hasil pemeriksaan (LHP).

Dalam laporan hasil audit tersebut terdiri dari :

1. Ringkasan hasil audit dan saran, mencakup : penilaian umum, temuan hasil audit, informasi tambahan, tindak lanjut temuan audit lalu.

2. Uraian hasil audit, terdiri dari :

a. Umum: (1) dasar audit, (2) obyek audit, (3) jenis audit, (4) periode dan waktu, (5) sasaran audit.

b. Kegiatan yang diaudit: (1) temuan positif yang meningkatkan kinerja perusahaan, (2) temuan yang memerlukan perbaikan manajemen.

3. Informasi tambahan

4. Tindak lanjut

Laporan Hasil Pemeriksaan (LHP) yang telah diterbitkan tersebut akan dikirim kepada General Manajer. Hasil dari tindak lanjut temuan audit dalam LHP akan dipantau secara berkala berdasarkan laporan periodik. Tindak lanjut dari temuan tersebut akan mempengaruhi kinerja pelayanan hotel.

Berdasarkan pengamatan dan serta pengumpulan data-data selama penelitian, maka dapat diketahui bahwa secara keseluruhan langkah-langkah audit operasional yang dilakukan:

1. Perencanaan (planning)

Pada tahap ini, auditor pelaksana harus menentukan lingkup audit operasional dan mengkomunikasikannya kepada unit organisasi yang ada. Hal lain yang harus dilakukan antara lain, mengumpulkan banyak informasi berkaitan dengan latar belakang unit organisasi, memahami pengendalian internalnya dan memperkirakan bukti yang harus dikumpulkan nantinya. Pada tahap ini telah sesuai dengan pelaksanaan audit operasional aktivitas pelayanan jasa penginapan hotel dimana proses perencanaan dimulai dengan usulan audit, kemudian dituangkan dalam PKAT (Program Kerja Audit Tahunan). Dalam PKAT tersebut ditentukan berkaitan dengan jenis audit, obyek audit, periode audit, waktu pemeriksaan. Namun demikian terdapat kekurangan yaitu,

Kondisi :

Tidak dicantumkan tenaga pemeriksa yang diperlukan dalam PKAT.

i. Kriteria

Kegiatan perencanaan pemeriksaan mencakup jenis pemeriksaan, perkiraan waktu, pengaturan tenaga pemeriksaan, pengaturan biaya pemeriksaan.

ii. Penyebab

Pada penentuan PKAT dengan waktu pelaksanaan audit masih cukup lama. 


\section{iii. Akibat}

Kurangnya kesiapan personil dalam melaksanakan pemeriksaan nantinya.

iv. Rekomendasi

Sebaiknya dalam PKAT sudah disusun tim audit agar para personil audit dapat mempersiapkannya dengan matang.

Tahap kerja perencanaan yang lain adalah mengumpulkan banyak informasi berkaitan dengan latar belakang aktivitas pelayanan jasa penginapan hotel. Pada tahap ini beberapa auditor dari tim audit melaksanakan survei pendahuluan terhadap obyek audit. Survei pendahuluan yang dilakukan bersamaan dengan penyampaian surat tugas audit kepada unit kerja terkait. Karena audit operasional pada aktivitas pelayanan jasa penginapan relatif sama dengan aktivitas audit sebelumnya yang telah dilakukan oleh pengawas bidang yang sama, menurut penulis survei pendahuluan ke lapangan yang dilakukan kurang mendalam. Hal ini berkaitan dengan keterbatasan waktu dan sumber daya yang ada.

2. Pengumpulan bukti dan pengevaluasian ( evidence accumulation and evaluation )

Pengumpulan bukti dapat dilakukan dengan menggunakan dokumendokumen yang ada, wawancara dengan pihak-pihak yang berkaitan dengan obyek audit operasional dan observasi. Proses pengumpulan bukti yang telah dilaksanakan oleh auditor tercermin dalam program audit. Program audit yang telah dibuat tersebut telah memuat dengan petunjuk tertulis mengenai instruksi umum dan prosedur audit yang harus dilaksanakan oleh auditor. Pengumpulan bukti yang dilakukan selama proses audit operasional aktivitas pelayanan jasa penginapan hotel antara lain dengan penelaah proses pelayanan jasa penginapan mulai dari perencanaan, pengorganisasian kegiatan dan pengawasan. Serta pemeriksaan atas dokumen-dokumen yang berkaitan dengan aktivitas pelayanan jasa penginapan hotel.

3. Pelaporan dan menindaklanjuti ( reporting and follow-up)

Hasil dari pelaksanaan audit operasional merupakan laporan hasil audit, dimana dalam laporan tersebut memuat lingkup pelaksanaan audit, temuan audit yang berkaitan dengan unit kerja auditee, serta adanya rekomendasi.Berdasarkan hasil pengamatan atas Laporan Hasil Pemeriksaan (LHP) yang telah dibuat oleh SPI PT. Equator Dayatama Semesta atas aktivitas pelayanan hotel, didalamnya telah memuat unsur-unsur laporan hasil audit yang telah disebutkan sebelumnya. Didalam laporan hasil audit operasional aktivitas pelayanan jasa penginapan hotel, meliputi : (1) ringkasan hasil audit dan saran; (2) uraian hasil audit; (3) informasi tambahan; (4) tindak lanjut.

\section{Evaluasi Efektivitas Pelaksanaan Audit Operasional Aktivitas Pelayanan Jasa Penginapan Hotel}

Tidak ada ukuran yang pasti untuk menghitung tercapainya efektivitas suatu pelaksanaan audit operasional, namun demikian banyak sumber menyatakan bahwa efektivitas dapat dicapai (Wilborn: 2000). Penilaian efektivitas yang dilakukan 


\section{AKRUAL}

Jurnal Akuntansi

http://fe.unesa.ac.id/ojs/index.php/akrl

mengacu pada kriteria yang ada pada Norma SPI dan SOP. Apabila kriteria yang ada telah dipenuhi dalam proses pelaksanaan di lapangan maka dikatakan 'efektif', tetapi apabila terdapat kelemahan yang muncul maka pelaksanaan tersebut dikatakan ' 'cukup efektif'. Pertimbangan lain yang mendasari adalah hasil wawancara serta kuisioner terhadap pelaksanaan audit operasional.

Kriteria yang digunakan oleh penulis dalam penilaian efektivitas pelaksanaan audit operasional aktivitas pelayanan jasa penginapan hotel mengacu pada SOP (Standart Operating Procedure) Departemen Front office, dengan rincian sebagai berikut:

1. Independensi

Dengan melihat struktur organisasi PT. Equator Dayatama Semesta telah menunjukkan bahwa unit kerja internal audit sudah sangat independen dari berbagai macam kegiatan operasional lain di perusahaan yang menjadi obyek audit (auditee).

a. Status Organisasi

Status organisasi Satuan Pengawasan Intern (SPI) telah didefinisikan dengan jelas dan terpisah dari unit kerja lain dalam perusahaan.

Satuan Pengawasan Intern juga telah memiliki pedoman formal berkaitan dengan perencanaan, penjadwalan, serta proses pengendalian dalam melakukan kegiatan pemeriksaan. Sehingga dapat disimpulkan bahwa status organisasi Satuan Pengawasan Intern telah cukup mendukung keleluasaan untuk memenuhi dan menyelesaikan tanggung jawab pemeriksaan yang diberikan.

b. Obyektifitas

Obyektifitas adalah sikap mental yang harus dimiliki oleh auditor untuk melakukan pemeriksaan. Auditor tidak boleh menempatkan penilaian sehubungan dengan pemeriksaan yang dilakukan secara lebih rendah dibandingkan dengan penilaian yang dilakukan oleh pihak lain atau menilai sesuatu berdasarkan hasil penilaian orang lain. (Tugiman, 2005:24). Hal-hal yang mendukung obyektifitas pemeriksaan antara lain : (1) menghindari seminimal mungkin terjadinya konflik kepentingan antara auditor dengan pihak auditee; (2) auditor tidak boleh menerima tanggung jawab operasional; (3) adanya rotasi penugasan staff audit secara periodik bila mungkin dilakukan.

Berdasarkan hasil wawancara atas jawaban kuisioner, terdapat beberapa hal yang dapat mendukung obyektifitas Satuan Pengawasan Intern, diantaranya : (1) selalu dilakukannya koordinasi dan komunikasi dengan Kepala Satuan Pengawasan Intern berkaitan dengan konflik kepentingan yang potensial terjadi selama pelaksanaan proses pemeriksaan untuk tetap selalu mendukung obyektifitas auditor; (2) para auditor tidak menerima tanggung jawab operasional pada unit kerja auditee karena secara organisasi Satuan Pengawasan Intern merupakan unit kerja yang independen dari kegiatan 


\section{AKRUAL}

Jurnal Akuntansi

http://fe.unesa.ac.id/ojs/index.php/akrl

operasional lain perusahaan. Berkaitan dengan rotasi penugasan audit operasional pada aktivitas pelayanan jasa penginapan, menurut jawaban kuisioner dan hasil wawancara didapatkan informasi bahwa penugasan audit operasional pada aktivitas tersebut tidak ada rotasi penugasan audit. Hal ini disebabkan karena tanggung jawab untuk melakukan audit operasional pada aktivitas pelayanan jasa penginapan merupakan tugas pada Pengawas Bidang Operasi, Pemasaran, Perencanaan, dan Pengembangan dengan anggota auditor pelaksana yang relatif tetap dengan tahun-tahun sebelumnya. Rotasi penugasan dimungkinkan, yaitu perpindahan tugas auditor pelaksana dari satu departemen ke departemen lain atas persetujuan Kepala Satuan Pengawasan Intern, tetapi hal ini jarang sekali terjadi karena terbatasnya jumlah auditor serta banyaknya obyek yang harus diaudit pada setiap tahunnya.

Dengan kondisi seperti penjelasan di atas, menurut penulis memiliki kelebihan dan kelemahan yang mungkin muncul. Kelebihan yang sangat menguntungkan adalah dengan adanya penugasan pemeriksaan oleh auditor yang tetap pada setiap tahunnya, staff auditor tersebut akan lebih dapat meningkatkan profesionalismenya karena adanya spesialisasi pada bidang audit masing-masing. Namun demikian, terdapat juga kelemahan yaitu :

Kondisi :

Tidak adanya rotasi penugasan audit operasional pada aktivitas pelayanan jasa penginapan hotel.

i. Kriteria

SPI melakukan rotasi penugasan staff bagian audit secara periodic

ii. Penyebab

Tanggung jawab untuk melakukan audit operasional pada aktivitas pelayanan jasa penginapan merupakan tugas pada pengawas bidang operasi, pemasaran, perencanaan dan pengembangan dengan anggota auditor pelaksana yang relatif tetap dengan tahun-tahun sebelumnya.

iii. Akibat

Dapat berkurangnya obyektifitas dari auditor yang melaksanakan pemeriksaan karena mereka melakukan audit pada unit kerja yang sama untuk periode audit yang berturut-turut.

iv. Rekomendasi

Perlu dilakukannya rotasi penugasan audit secara periodik terhadap auditor, agar auditor yang melakukan audit pada obyek ini bukan auditor yang sama dengan yang melakukan audit tahun sebelumnya.

2. Kemampuan Profesional

Dengan kemampuan profesioanl yang layak, auditor akan dapat melaksanakan tugas pemeriksaan dengan baik. berdasarkan hasil jawaban kuisioner dapat diketahui bahwa Kepala Satuan Pengawasan Intern telah menetapkan kriteria pendidikan dan pengalaman yang sesuai dengan penugasan pemeriksaan pada obyek audit. 


\section{AKRUAL}

Jurnal Akuntansi

http://fe.unesa.ac.id/ojs/index.php/akrl

Secara keseluruhan, staff Satuan Pengawasan Intern telah memahami dan mampu menerapkan standar pemeriksaan, prosedur, dan teknik pemeriksaan. Seluruh personil SPI telah mengikuti pendidikan dan pelatihan untuk dapat mendukung program pendidikan berkelanjutan. Hal lain yang mendukung adalah personil SPI berasal dari berbagai disiplin ilmu serta perekrutan anggota SPI pun berasal dari unit kerja pada PT. Equator Dayatama Semesta, sehinga sangat memungkinkan bahwa auditor benar-benar memahami obyek audit yang akan diperiksa.

Pada audit operasional aktivitas pelayanan jasa penginapan, dapat diketahui bahwa pemahaman tahapan dan teknik audit operasional dapat dikatakan cukup baik, hal ini tercermin dari kertas kerja audit yang telah dibuat.

3. Pelaksanaan Kegiatan Pemeriksaan

a. Perencanaan pemeriksaan

Perencanaan pemeriksaan adalah semua kegiatan yang dilakukan oleh Satuan Pengawasan Intern PT. Equator Dayatama Semesta sebelum kegiatan audit operasional aktivitas pelayanan jasa penginapan tersebut dilaksanakan. Kegiatan ini dimulai pada saat tim audit pada rapat PKAT (Program Kerja Audit Tahunan), kemudian pembuatan surat tugas, survei pendahuluan dan pembuatan program audit.

Berdasarkan jawaban kuisioner dapat disimpulkan bahwa dalam proses perencanaan awal tersebut telah terdapat penetapan jangka waktu pemeriksaan, periode pemeriksaan, dan lingkup pemeriksaan. Termasuk juga perencanaan berkaitan dengan jumlah dan tingkat pengalaman personil tim audit, kecakapan dan disiplin ilmu staff audit.

Berdasarkan tahap awal perencanaan yang telah dijalankan oleh tim audit operasional aktivitas pelayanan jasa penginapan hotel dapat dikatakan cukup baik. Tahap selanjutnya setelah dilakukan survei pendahuluan adalah pembuatan program audit. Program audit yang ada pada aktivitas pelayanan jasa penginapan hotel bersifat standar, karena audit pada aktivitas ini bersifat teratur pada setiap tahunya. Pembuatan program pemeriksaan yang sudah terstandarisasi akan meningkatkan efisiensi pemeriksaan dan memudahkan pendelegasian pemeriksaan (Tugiman, 2005: 66). Namun demikian menurut penulis, hal ini memiliki kelemahan yaitu :

Kondisi :

Setelah melakukan survey pendahuluan tidak membuat program audit.

i. Kriteria

Setelah melakukan survey pendahuluan, kemudian dibuat program pemeriksaan.

ii. Penyebab

Program audit yang sudah terstandarisasi dan bersifat teratur pada tiap tahunnya. 


\section{AKRUAL}

Jurnal Akuntansi

http://fe.unesa.ac.id/ojs/index.php/akrl

iii. Akibat

Dengan adanya program audit yang sudah terstandar tersebut nantinya tidak menutup kemungkinan bahwa survey pendahuluan yang dilaksanakan kurang begitu mendalam dan bersifat formalitas semata.

iv. Rekomendasi

Hendaknya lebih melakukan pengembangan terhadap program audit yang terstandar untuk meningkatkan kualitas audit.

b. Pengujian dan pengevaluasian bukti

Proses pengujian dan pengevaluasian bukti audit operasional pelayanan jasa penginapan hotel tercermin dalam kertas kerja yang dibuat oleh auditor. Dalam melaksanakan audit operasional tersebut, Satuan Pengawasan Intern melakukan evaluasi secara menyeluruh terhadap pengendalian manajemen berkaitan dengan organisasi, kebijakan/ aturan, prosedur-prosedur, personalia,/ SDM, aspek perencanaan, pengorganisasian kegiatan, pelaporan dan pengawasan manajemen. Auditor juga melaksanakan prosedur pemeriksaan untuk menghasilkan bukti yang berkaitan dengan membandingkan informasi saat ini dengan informasi sejenis pada periode sebelumnya, membandingkan informasi dalam periode saat ini dengan anggaran (forecast). Dalam hal ini auditor melakukan penilaian tentang investasi sarana pelayanan hotel, kinerja pelayanan hotel, pendapatan dan biaya berkaitan dengan jasa pelayanan hotel, serta produktifitas pelayanan hotel. Hasil evaluasi dari setiap langkah kerja pemeriksaan dengan format yang terdiri dari nomor kertas kerja audit, judul kertas kerja audit, unit kerja auditee, periode audit, data tim auditor, nomor surat tugas, supervisor kertas kerja audit.

Berdasarkan jawaban kuisioner dan hasil wawancara diketahui bahwa kertas kerja yang dibuat oleh auditor benar-benar di-review oleh pengawas pada tim audit yang melaksanakan audit operasional pelayanan jasa penginapan hotel. Review atas kertas kerja tersebut bertujuan untuk memastikan bahwa program pemeriksaan telah dijalankan, serta menentukan apakah tujuan pemeriksaan telah dicapai atau belum. Pengamatan penulis atas kertas kerja audit yang telah dibuat oleh auditor telah mencakup aspek-aspek perencanaan, pengujian dan evaluasi kecukupan serta keefektifan sistem pengendalian internal, prosedur pemeriksaan yang telah dilaksanakan, peninjauan (review) oleh pengawas, pelaporan dan menindak lanjuti.

c. Penyampaian hasil pemeriksaan

Selama proses pemeriksaan, apabila ditemukan keadaan yang tidak sesuai dengan kriteria yang ditetapkan sebelumnya, auditor akan melakukan diskusi dengan tim audit kemudian dilakukan konfirmasi dengan unit kerja terkait. Hal ini dilakukan untuk memastikan bahwa tidak terdapat kesalahpahaman atau kesalahan penafsiran terhadap fakta yang di dapat, serta memberikan kesempatan kepada pihak yang diperiksa untuk menjelaskan berbagai hal 
tertentu dan mengemukakan pendapatnya terhadap kegiatan pemeriksaan (berdasarkan hasil wawancara).

Setelah dilakukan pembicaraan dengan unit kerja terkait aktivitas pelayanan jasa penginapan hotel terhadap temuan audit, kemudian dilakukan rapat pembahasan antara pihak manajemen aktivitas pelayanan jasa penginapan hotel, General Manajer, Komite audit serta Kepala Satuan pengawasan Intern PT. Equator Dayatama Semesta sebagai penengahnya. Dalam rapat tersebut dilakukan pembahasan tentang pelaksanaan audit operasional yang telah dilaksanakan, temuan audit dan pembahasan lebih lanjut tentang hasil pemeriksaan sebelum Laporan Hasil Pemeriksaan (LHP) diterbitkan.

Didalam Laporan Hasil Pemeriksaan yang dibuat tersebut memuat tentang maksud, lingkup dan hasil pelaksanaan pemeriksaan. Dalam hasil pemeriksaan tersebut telah memuat kriteria, kondisi, sebab dan akibat. Karena keterbatasan penulis untuk memperoleh informasi tentang isi LHP secara keseluruhan, berdasarkan hasil pengamatan, wawancara dan kuisioner dapat disimpulkan bahwa isi LHP tersebut telah cukup efektif.

d. Tindak lanjut hasil pemeriksaan

Laporan Hasil Pemeriksaan (LHP) yang telah diterbitkan tidak akan berguna apabila tidak dilakukannya tindak lanjut atas rekomendasi yang diberikan oleh auditor. Tindak lanjut yang dilakukan oleh unit kerja terkait dengan aktivitas pelayanan jasa penginapan hotel kemudian dipantau secara periodik. Satuan Pengawasan Intern PT. Equator Dayatama Semesta membuat laporan secara periodik hasil tindak lanjut yang dilakukan oleh unit kerja terkait. Representasi telah dilakukannya rekomendasi yang diberikan oleh Satuan Pengawasan Intern Terdapat dalam hasil laporan periodik kinerja aktivitas pelayanan jasa penginapan pada Hotel Equator Surabaya.

Berdasarkan hasil wawancara dengan staff Audit, diperoleh informasi bahwa pelaksanaan rekomendasi dari tim audit dengan melaksanakan proses tindak lanjut yang disarankan oleh Sartuan Pengawasan Intern mampu meningkatkan mutu pelayanan terhadap tamu. Menurut penulis, dengan adanya kebijakan tersebut sangat mendukung efektivitas audit operasional karena tujuan audit benar-benar dapat dicapai dan manajemen pun menjadi semakin termotivasi untuk terus melakukan perbaikan.

\section{SIMPULAN DAN SARAN}

Berdasarkan hasil pembahasan dan evaluasi terhadap efektivitas pelaksanaan audit operasional aktivitas pelayanan jasa pada Hotel Equator, dapat disimpulkan bahwa:

1. Independensi auditor yang melaksanakan audit operasional aktivitas pelayanan jasa penginapan hotel yaitu Satuan Pengawasan Intern sudah sangat independen, karena sudah ada prosedur dasar berkaitan dengan status organisasi, kedudukan, tugas, tanggung jawab dan wewenang Satuan Pengawasan Intern. 
AKRUAL 3 (1) (2011): 86-113 e-ISSN: 2502-6380

\section{AKRUAL}

Jurnal Akuntansi

http://fe.unesa.ac.id/ojs/index.php/akrl

2. Obyektifitas auditor yang melaksanakan secara keseluruhan dapat dikatakan obyektif, karena sebagian besar unsur-unsur obyektifitas sudah dapat dipenuhi oleh Satuan Pengawasan Intern PT. Equator Dayatama Semesta.

3. Adanya pedoman pelaksanaan audit yang memadai oleh Satuan Pengawasan Intern yang memadai untuk mendukung pelaksanaan audit operasional pelayanan jasa penginapan hotel.

4. Pelaksanaan audit operasional didukung oleh kemampuan profesional yang layak oleh auditor, dimana auditor telah memiliki pengetahuan dasar tentang audit dan pemahaman operasional tentang obyek auditee.

5. Perencanaan kegiatan pemeriksaan dapat dikatakan cukup efektif karena telah mencakup aspek perencanaan yang memadai.

6. Proses pengumpulan dan pengevaluasian bukti audit operasional sudah efektif, karena prosedur audit yang telah dibuat dijalankan dengan baik.

7. Penyampaian hasil pemeriksaan cukup efektif, hal yang mendukung efektivitas tersebut adanya konfirmasi terlebih dahulu pada unit kerja terkait aktivitas pelayanan jasa penginapan hotel dan adanya rapat dalam pembuatan laporan hasil pemeriksaan.

8. Pelaksanaan dalam pelayanan tehadap tamu belum sepenuhnya berdasarkan Standart Operation Prosedure.

\section{Saran}

Saran dari penulis berkaitan dengan kelemahan yang mungkin muncul dari pelaksanaan audit operasional yang telah dijalankan, antara lain :

1. Satuan Pengawasan Intern PT. Equator Dayatama Semesta agar lebih banyak memberikan pelatihan tambahan kepada tim audit yang berkaitan dengan proses pengauditan. Sehingga dalam pelaksanaan proses audit mereka benar-benar bisa memahami dan dapat melaksanakan dengan baik.

2. Pada kegiatan survei pendahuluan hendaknya dilakukan lebih mendalam, walaupun proses operasional aktivitas pelayanan jasa penginapan hotel relatif sama dan teratur tetapi tidak menutup kemungkinan terjadinya perubahanperubahan yang ditimbulkan pada aktivitas di lapangan. Sehingga pemahaman dan pengumpulan informasi dasar tentang obyek auditee benar-benar menyeluruh.

3. Standart Operating Procedure pelayanan jasa hotel sebaiknya dilakukan pengembangan demi untuk meningkatkan mutu pelayanan terhadap konsumen/ tamu. 
AKRUAL 3 (1) (2011): 86-113 e-ISSN: 2502-6380

AKRUAL

Jurnal Akuntansi

http://fe.unesa.ac.id/ojs/index.php/akrl

\section{DAFTAR PUTAKA}

Arens, Alvin, Randal. J. Elser and Mark Beasley.2003. Auditing an Integrated Approach. New Jersey: Prentice Hall International.

Boynton, Johson, Kell. 2001. Modern Auditing seventh edition. USA : John Willey and Sons.

Halim, Abdul. 2001. Auditing (Dasar-dasar audit laporan keuangan) edisi kedua (edisi revisi). Yogyakarta : UPP AMP YKPN.

Jusup. A.L, Haryono. 2001. Auditing (pengauditan) cetakan pertama. Yogyakarta : STIE (Sekolah Tinggi Ilmu Ekonomi).

Mulyadi. 2001. Sistem Akuntansi edisi ketiga cetakan ketiga. Jakarta : Salemba Empat.

2002. Auditing edisi keenam cetakan pertama. Jakarta : Salemba Empat.

Rangkuti, Freddy. 2000. Manajemen Persediaan Aplikasi di Bidang Bisnis. Jakarta:PT. Raja Grafindo Persada.

Reider, Rob.2002. Operational Review edisi ketiga. New York : John Willey \& Sons, Inc.

Sawyer, Lawrence.B, Dittenhofer, Mortimer. A, Scheiner, James. H. 2005. Sawyer's Internal Auditing edisi kelima buku ketiga. The Instite of Internal Auditors. Terjemahan diterbitkan Penerbit Salemba Empat.

Simamora, Hendry. 2002. Auditing I cetakan pertama. Yogyakarta : UPP AMP YKPN.

Sukrisno Agoes. 2000. Auditing (Pemeriksaan Akuntan) oleh Kantor Akuntan

Publik edisi kedua cetakan kedua. Jakarta : Fakultas Ekonomi Universitas Indonesia.

Sunarto. SE, MM. 2003. Auditing edisi revisi cetakan pertama. Yogyakarta: Panduan.

Tunggal, Amin Widjaja. 2000. Audit Manajemen Kontemporer edisi revisi. Jakarta: Harvindo. . 2000. Internal Auditing (suatu pengantar). Jakarta : Harvindo. 